\title{
ASSOCIATION OF NUTRITION AND OVERCROWDED ON THE RISK OF PULMONARY TUBERCULOSIS IN SAMOSIR DISTRICT NORTH SUMATERA
}

\author{
Helpi Sitanggang ${ }^{1}$, Fazidah Aguslina Siregar ${ }^{2}$, Nurmaini $^{3}$ \\ ${ }^{1}$ School of Public Health, Faculty of Public Health,University of Sumatera Utara. \\ ${ }^{2}$ Department of Epidemiologi, Faculty of Public Health, Universitas Sumatera Utara. \\ ${ }^{3}$ Department of Environtment, Faculty of Public Health, Universitas Sumatera Utara. \\ Email:'helpi_ent@yahoo.co.id, ${ }^{2}$ fazidah@usu.ac.id, ${ }^{3}$ nurmainik@yahoo.com
}

\begin{abstract}
Background: Pulmonary tuberculosis is an infection diseases that continues to increase morbidity and mortality in Indonesia. In 2017, the cases of pulmonary TB in Samosir District was 252 cases, with incidence rate a smear-positive of 126 per 100,000 population. Smear positive pulmonary tuberculosis potential to infect other people who living in the same environtment.

Materials and Methods: This study aims to determine the association of nutritional status and lighting withsmear positive pulmonary tuberculosis. Methods: A case-control study was conducted among 63 cases of smear-positive pulmonary tuberculosis and 63 controls without pulmonary tuberculosis. The cases were retrieved from the TB Registry at health centre in Samosir District. The cases were recruited from June 2018 to March 2019. Data was collected using a set of questionnaireby interview. Simple logistic regressionwas used to compute the crude odds ratio for the association of nutritional and lighting with smear-positive pulmonary tuberculosis.
\end{abstract}

Result: This study indicated that there was an association of poor nutrition status $(O R=4.280$; 95\% CI: 1.849, 9.906), and an overcrowded (OR = 5.084;95\% CI: 1.852, 13,995) with the incidence of smear-positive pulmonary TB in Samosir District.

Conclusion: The conclusion of this study there was an association between poor nutritional status and an overcrowded with smear-positive pulmonary TB in Samosir District. Some interventions needed including strengthening health promotion and supplementary feeding to TB patient.

Keywords: nutritional status, overcrowded, pulmonary tuberculosis.

\subsection{Introduction}

Tuberculosis (TB) is a global health problem that is increasing every year. During 2017, one point three million people were reported dead due to TB infection in adults with a negative HIV test and an increase in deaths due to TB and HIV positive co-infections by 300 thousand according to the World Health Organization (WHO, 2018).
Estimates of sufferers globally in 2017 show that 10 million people suffer from TB consisting of five point eight million men, three point two million women and one million children. All cases were found spread in all countries and infect all age groups.

Ninety percent attack adults with age above 15 years and 10 percent infect children under 15 
years. Two-thirds of cases were in eight countries, namely India at 27 percent, China nine percent, Indonesia eight percent, Philippines six percent, Pakistan five percent, Nigeria four percent, Bangladesh four percent and South Africa three percent (WHO, 2018).

Naramsinhan (2013) in his research on TB risk factors conducted in India, said that transmission occurs due to exposure to risk factors with the source of the case (Mycobacterium tuberculosis). The combination of intrinsic factors such as age, sex and social factors including occupation, contact history, nutritional status, immunization status, occupancy density and smoking behavior contribute to accelerate TB transmission. Pittalis et al. (2017) stated that the proportion of TB sufferers in the migrant population in Italy experienced material losses as much as four times higher than in patients with young age and eight times greater than in older people in native Italy. That indicates that the low socioeconomic status contributes to the risk of TB incidence.

Data and information Ministry of Indonesia center states that Indonesia ranks third in the world in the TB problem after India and China. According to that data states that men are more susceptible to TB infection by one point four times than women. This can be caused by men having high mobility such as farmers, fishermen, builders who need stronger energy compared to women who only stay at home as housewives so that men are more likely to be exposed to TB germs. The data is in accordance with the prevalence survey conducted by health research and development agencies in all districts and cities in Indonesia in 2013-2014. The survey results show that the prevalence of men is three times higher than that of women. This can arise because men are more exposed to risk factors for example smoking. Male respondents who smoked in this study were 68.5 percent and women were 31.5 percent (Republik Indonesia Ministry of Health's, 2017).

Based on data obtained from the P2 TB section of the North Sumatra Provincial Health Office in 2017 the achievement of cases in the Districts / Cities in the three highest sequences was Medan with 3,231 / 100,000, Deliserdang Regency with 2,084 / 100,000 and Simalungun with 944 /
100,000. While the 3 lowest regencies and cities are Binjai District 65 / 100,000, Pakpak Bharat at 76 / 100,000 and West Nias at 110 / 100,000 (Provincial Health Office, 2018).

The number of new TB smear positive cases finding in Samosir District started in 2016 with Case Notification Rate recorded in the regency register were 115 / 100,000 pulmonary TB population, in 2017 there were 126 / 100,000 population. One indicator used in control is the Case Detection Rate (CDR), which is the proportion of new positive smear pulmonary TB patients found and treated against the number of new smear positive pulmonary TB patients who are estimated to exist in one region (Samosir District Health Office, 2018).

Based on a preliminary survey conducted on June 28, 2018, patients in public Health centre working area of the Samosir District Health Office found 154 cases all types of TB, consisting of positive smear pulmonary TB, Extra Lung, X-ray and relapse. The results of the case finding in Samosir District were dominated by sputum examination for a diagnosis of TB smear positive compared to other diagnoses, which was 61 percent. Cases data in Samosir District was sourced from 12 puskesmas spread across 9 sub-districts. Patient classification from 154 new cases found consisted of 135 cases of pulmonary TB smear positive, 12 cases of extra lungs, 6 cases recurred and 1 case dropout. (Samosir District Health Office, 2018).

Incidence rate of pulmonary TB smear positive by age group in Samosir remains high, namely less than 34 years of 39 cases, 34 to 54 years was 65 cases, 55 to 74 years at 45 cases and the age group over 74 years at 5 cases in the age group 35 to 54 years the incidence of pulmonary $\mathrm{TB}$ in productive age. The percentage of cases of pulmonary TB smear positive in Samosir District more dominant on the male $73 \%$ compared with $23 \%$ t of women.

Based on the fact that pulmonary TB smear positive is still a basic public health problem in Samosir District with a trend of incidence rate starting from 2015 which is $123 / 100,000$ population of $164 \mathrm{~TB}$ cases of all types, throughout 2016 is 115 / 100,000 population of 
262 TB cases of all types, and in 2017 with 126 new cases / 100,000 population of $252 \mathrm{~TB}$ cases of all types.

Based on that problem researcher wants to determine the association between nutritional status and population density on the risk pulmonary TB smear positive in Samosir District.

\subsection{Materials and Methods}

Type of this research is using an observational analytic epidemiological study with a casecontrol study design that aims to examine the association between certain effects (diseases or health conditions) with risk factors comparing case groups and control groups (Sastroasmoro, 2014). The location of this study was carried out in four Public Health Centre (PHC) in Samosir District among of theme Buhit PHC, Sirait PHC, Lontung PHC and Simarmata PHC than this research was conducted from June 2018 until complete. The sample of this research is aged after 15 years old who are living the area of four PHC starting from an area with a larger population proces to the next PHC. Sample size consists of 63 respondents in cases group and 63 in control group. andstarting from the most populous puskesmas and proceed to the next puskesmas until the number of samples is 63 cases and 63 controls compare between cases and control one to one than total sample was 126 person. Sampling tehnique in this study was proportional random sampling.

The collection primary data obtained through interview with questionnaires and take measurement of nutritional status. Secondary data were obtained from reports District Health Office or documents Buhit PHC, Sirait PHC, Simarmata PHC, Lontung PHC and other data wich relevant to this research problems. Data analysis is univariate, bivariate with simple logistic regression and multivariate analysis with multiple logistic regression tests. status in patients with smear-positive pulmonary TB is the respondents in the cases group with less category (BMI <18.5) is $65 \%$ and respondents in the control group is $25 \%$ and overcrowded wich uneligible were in cases group (44\%) and (7\%) in control group.

\subsection{Bivariate Analysis}

This analysis was conducted with a simple logistic regression model test that mean the variable of nutritional status and overcrowded have $\mathrm{p}$ value less than 0,25 so that they can recomended multivariate analysis modeling with Multiple Logisticn Regression test.

Tabel 1 Association of nutrition and overcrowded on the risk of pulmonary Tuberculosis in Samosir District North Sumatera

\begin{tabular}{lcccc}
\hline \multirow{2}{*}{ Variable } & \multicolumn{3}{c}{ Pulmonary TB Incidence } \\
\cline { 2 - 5 } & $\begin{array}{c}\text { TB smear positive } \\
\text { (cases) }\end{array}$ & \multicolumn{2}{c}{$\begin{array}{c}\text { Without TB } \\
\text { (control) }\end{array}$} \\
\cline { 2 - 6 } & $\mathrm{n}$ & $\%$ & $\mathrm{n}$ & $\%$ \\
\cline { 2 - 5 } Nutritional Status & & & & \\
BMI $(<18,5)$ & 41 & 65 & 16 & 25 \\
$\quad$ Normal $(\geq 18,5)$ & 22 & 35 & 47 & 75 \\
Overcrowded & & & & \\
Uneligible & 24 & 44 & 7 & 11 \\
Eligible & 35 & 56 & 56 & 89 \\
\hline
\end{tabular}

\subsection{Multivariate Analysis}

This model can explain that people who factor nutritional status less than 18,5 (BMI <18.5) and uneligible overcrowded on the risk of pulmonary TB in Samosir District. The result of this analysis shows that the independent variable can predict dependent variable by 92,3 percent and 7,7 percent influences by other risk factors.

\subsubsection{Table 2}

Summary Results of Multivariate Analysis

Based on Multiple Logistic Regression Test

Results

\subsection{Result}

\subsection{Univariate Analysis}

\begin{tabular}{rrrrrr}
\hline Variable & B & Sig. & OR & \multicolumn{2}{c}{ 95\% CI } \\
\cline { 5 - 6 } & & & & Lower & Upper \\
\hline 1,454 & 0,001 & 4,280 & 1,849 & 9,90 \\
1,626 & 0,002 & 5,084 & 1,852 & 13,9 \\
& 1,677 & 0,000 & 0,187 & & -
\end{tabular}

Based on the results of research conducted in $-1,677$

0,000

0,187

Samosir District indicate that the nutritional 


\subsection{DISCUSSIONS}

\subsection{Association of Nutritional status on the risk pulmonary TB smear positive incidence in Samosir District}

According to multivariate analysis using multiple logistic regression, the value of odds ratio is 4.280 (95\% CI 1.849-9.906) it means that respondents whose nutritional status is less than 18,5 (BMI <18.5) have a risk of 4.280 times to be infected with pulmonary TB smear positive compared to respondents with normal nutritional status (BMI $\geq 18.5)$.

This study found that respondents with pulmonary TB smear positive is a resident who has a weak economic level so that respondents are not able to meet the required nutrient intake. It can happen because respondents pulmonary TB smear positive is not working because of illness so that income there is not to meet the nutritional adequacy.

Efforts that can be made to improve nutritional status are utilizing home yards to grow vegetables to meet nutritional intake and backyard farms for raising chickens so that they can help to meet the nutritional intake of respondents pulmonary TB smear positif.

Efforts made by the TB prevention and control program (P2PM) Office Health District do counseling related to the danger posed by tuberculosis through a campaign of tuberculosis in the community assisted by officers tuberculosis community health center program. This effort is also coupled with the distribution formula for patients with pulmonary TB smear positive.

Kant et al (2015) states that nutrition has a significant association to the incidence of pulmonary TB where malnutrition associated with impaired immune function and normal health system responsible for immunity as a defense against a variety of infectious diseases such as pulmonary TB.

\subsection{Association of overcrowded on the risk pulmonary TB smear positive incidence in Samosir District}

Based on research conducted in four health centers in Samosir District shows that most groups of patients with smear-positive pulmonary TB in residential density category are uneligible for 28 homes (44\%) and among those with pulmonary TB instead of $7(11 \%)$. Multivariate analysis using multiple logistic regression obtained $\mathrm{p}$ value $=0.002 ; \mathrm{OR}=$ 5,$084 ; 95 \%$ CI $1,852-13,955$ it means that respondents who have a residential density overcrowded do not meet health requirements $(<9 \mathrm{~m} 2$ / person) at risk of 5,084 times pulmonary TB smear positve compared to respondents whose occupancy density meets health requirements (>9 $\mathrm{m} 2 /$ person).

The conditions found in the study showed that most respondents pulmonary TB smear positive live in the house that serves as a dining room and bedroom at night without any barrier between the room in the house. If while the rooms are made in the respondent's house but did not match the size that qualify in accordance with the standards Permenkes in 2011 because the rooms are made only measures 1.5 by 2 meters.

In this study also found that family members who live in the house to sleep more than 2 people to sleep in the same room so that the possibility of transmitting Mycobacterium tuberculosis to other family members very quickly.

The house is occupied by respondents also serves as a storage of agricultural products such as onions, corn hung on the bottom of the roof of the house that serves to drain the agricultural products before being sold to the market. While the section under the house serves as a pet such as chickens and buffalo.

This study is according to Sumarni research (2012) in three health centers in North Lampung Regency indicate that there is the influence of density residential home with smear-positive pulmonary TB incidence. It means that the risk of smear positive pulmonary TB incidence is higher at 2,928 times the respondents who had not qualified residential density compared with the density of respondents eligible dwelling.

\subsection{Conclusion and recommendation}


4.1.1 There is association of nutritional status on the risk of pulmonary TB in Samosir District

4.1.2 There is association of overcrowded on the risk of pulmonary TB in Samosir District

4.1.3 The most dominant bariable on the risk of pulmonary TB smear positive is uneligible overcrowded with odds ratio value 5,084 (95\% CI 1,852-13,955), it means that respondents who have uneligible residential density have risk of 5,084 times to ifected pulmonary TB smear positive compare to respondents with eligible residential density.

\section{SUGGESTION}

1. Samosir District Health Office. As a policy maker to continue to improve the TB survey program in the work area of the puskesmas by involving all government and private sectors in TB prevention and control.

2. For all public health centres in Samosir District. Improving networking through village officials conducting TB campaigns, household contact with TB patients and tracking loss to follow-up cases so as not to become a source of transmission for people living together with smear positive pulmonary TB patients.

3. Community. People are more concerned about their health so that a clean and healthy living behavior associated with the understanding of a healthy home environment. It is expected that people do clean environment especially residential homes in the house does not take advantage of the ceiling of a house as a place of drying agricultural products, should be provided a special place outside the home as a place of drying agricultural products.

4. Researchers. The need for follow-up studies in order to understand better the factors that most influence with pulmonary TB smear positive.

\section{References}

Derseh, D., Moges, F., \& Tessema, B. (2017). Smear positive pulmonary tuberculosis and associated risk factors among tuberculosis suspects attending spiritual holy water sites in
Northwest Ethiopia. BMC Infectious.17(1) Diakses tanggal 16 Juni 2019. https://doi.org/10.1186/s12879-017-2211-5.

Dotulong, F.J., Sapulete, M.R., \& Kandou.,D.G. (2015). Relationship between gender age risk of residential density with the incidence of pulmonary TB disease in Wori village, Wori subdistrict 2015. (Jurnal Universitas Sam Ratulangi Manado) Accesed 28 Oktober 2018. https://ejournal.unsrat.ac.id.

Fatimah, S. (2008) Home environmental health factors associated with the incidence of pulmonary TB in Cilacap District (Sidareja District, Cipari, Kedungreja, Patimuan, Gandrangmangu, Bantasari). Accesed 27 November 2018; http://eprints.undip.ac.id.

Hastono, P. S. (2016). Analysis of data in the health sector (1 Edition). Jakarta: Rajawali Pers. Istiqomah, N., Indriani, N., \& Anwar, M., C. (2016). Relationship between the level of humidity of the house and the incidence of pulmonary tuberculosis in the District of Batang Regency. Accesed 31 Juli 2019. https://journal.unnes.ac.id/sju/index.php/ujph/art icle/view/11311

Indonesian Ministry of Health Data and Information Center (2017): Indonesian Health Profile. Accesed 26 November 2018; Dari http://www.pusdatin.kemkes.go.id.

Indonesian Lung Doctors Association. Guidelines for TB Management (TB Consensus) in Indonesia. Accesed dari http://www.medbox.org

Jendra, F. Margaret, R., \& Grace, D. (2014). Relationship between risk factors for age, sex and occupancy density with the incidence of pulmonary TB in Wori Village, Wori District. Diakses tanggal 10 Desember 2018; https://ejournal.unsrat.ac.id/index.php/JKKT/arti cle/view/7773/7336.

Kant, S., Gupta, H., \& Ahluwalia, S. (2015). Significance of nutrition in Pulmonary Tuberculosis. Critical Reviews in Food Science 
and Nutrition, 55(7), 955-963. Diakses tanggal $16 \quad 2017$

https://doi.org/10.1080/10408398.2012.679500.

Lemeshow, S., Hosmer, D., Klar, J., \& Lwanga S (1990). Adequacy of sample size in health studies. John Whiley \& Sons.

Sutiasih, L., Wirawan, D, N., \& A, A, S, Sawitri. (2013) Faktor risiko kejadian penyakit TB Paru di Puskesmas Karang Taliwang Kota Mataram Provinsi NTB Tahun 2013. (Laporan Hasil Penelitian Public Health and Preventive Medicine Archive)

https://www.researchgate.net/publication/33234 5454.

Malacarne, J., Kolte, I. V., Freitas, L. P., Orellana, J., Souza, M., Souza-Santos, R., \& Basta, P. C. (2018): Factors associated with TB in an indigenous population in Brazil: the effect of a cash transfer program. Revista do Instituto de Medicina Tropical de Sao Paulo, 60, e63.Diakses tanggal 22 November 2018 ; doi:10.1590/S16789946201860063.

Mangtani, P., Abubakar, I., Ariti, C., Beynon, R., Pimpin, L., Fine, P. E. M., \& Sterne, J. A. (2014). Protection by BCG vaccine against tuberculosis: A systematic review of randomized controlled trials. Clinical Infectious Diseases, 58(4), 470480. https://doi.org/10.1093/cid/cit790.

Masriadi.,H (2017). Epidemiology of Communicable Diseases,Edisi I. Depok: Rajawali Pers.

Muaz, F. (2014). Factors that influence the occurrence of BTA Lung Tuberculosis were positive in the Serang District health center in 2014. (Research Report of Syarif Hidayatullahh State Islamic University Jakarta). Accesed 3 Desember 2018; https://scholar.google.co.id.

Narasimhan, P., Wood, J., Macintyre, C. R., \& Mathai, D. (2013). Risk factors for tuberculosis. Pulmonary medicine. 2013;2013 (828939). Diakses tanggal 22 November 2018. https://scholar.google.co.id.
Nazmah. (2016). Epidemiologi penyakit menular. (Edisi ke-1). Jakarta: TIM.

Ndishimye, P., Domokos, B., Stillo, J., Seghrouchni, F., Mrabet, O., Homorodean, D., ... Sadak, A. (2016). A case control study of risk factors associated with pulmonary tuberculosis in Romania: Experience at a clinical hospital of pneumology. Medicine and Pharmacy Reports, 90(1), 54-59. https://doi.org/10.15386/cjmed652.

North Sumatra Province Health Office , (2016). Profile of District Health Office of North Sumatra Province. Medan.

Nurjana, M. A. (2015): Risk Factor of Pulmonary Tuberculosis on produktive age 15-49 years old in Indonesia. Balai Litbang P2B2 Donggala. Indonesia.

Padrão, E., Oliveira, O., Felgueiras, Ó., Gaio, A. R., \& Duarte, R. (2018). Tuberculosis and tobacco: Is there any epidemiological association. The European Respiratory Journal. 51 (1702121).

https://doi.org/10.1183/13993003.02121-2017.

Pittalis, S., Piselli, P., Contini, S., Gualano, G., Alma, M. G., Tadolini, M., Piccioni, P., ... Girardi, E (2017): Socioeconomic status and biomedical risk factors in migrants and native tuberculosis patients in Italy. 12 (12), Diakses tanggal $22 \quad$ November 2018 doi:10.1371/journal.pone.0189425.

Regulation of the Minister of Health of the Republic of Indonesia No. 67 of 2016 concerning Tuberculosis Control.

Regulation of the Minister of Health of the Republic of Indonesia No. 1077 of 2011 concerning Guidelines for Air Conditioning in House Spaces.

RI Ministry of Health. (2011). Practical Guidelines for Monitoring Adult Nutrition Status.Diakses tanggal 12 April 2019. Accesed from http://gizi.depkes.go.id 
RI Ministry of Health (2014), Indonesia Health Profile 2013. Jakarta : Ministry of Health RI, 2014. Accesed from http://pusdatin.kemkes.go.id

RI Ministry of Health (2014). Pedoman nasional pengendalian Tuberkulosis.

RI Ministry of Health (2018) Riset Kesehatan Dasar 2018. Diakses dari http:www.depkes.go.id

Samosir District Health Office, (2016). Samosir District Health Office Profile 2016. Pangururan.

Samosir District Health Office, (2017). Samosir District Health Office Profile 2017. Pangururan.

Sastroasmoro, S \& Ismael, S. (2014). Fundamentals of clinical research methodology (5th edition). Jakarta.

Sumarni \& Duarsa, A, B, S. (2012). Analysis of the relationship between the physical condition of the house and the positive pulmonary $T B$ incidence in Kotabumi II Health Center, Bukit Kemuning and Ulak Rengas, North Lampung District in 2012. (Journal of Yarsi Medicine).

Shimeles, E., Enquselassie, F., Aseffa, A., Tilahun, M., Mekonen, A., Wondimagegn, G., \& Hailu, T. (2019). Risk factors for tuberculosis: A case-control study in Addis Ababa, Ethiopia. 14(4).

https://doi.org/10.1371/journal.pone.0214235.

Senanayake, M., Wickramasinghe, S. I., Samaraweera, S., De Silva, P., \& Edirippulige, S. (2018): Examining the social status, risk factors and lifestyle changes of tuberculosis patients in Sri Lanka during the treatment period: a crosssectional study. 13 9. Accesed 22 November 2018;doi:10.1186/s40248-018-0121-z. 